International Journal of Current Advanced Research

ISSN: O: 2319-6475, ISSN: P: 2319 - 6505, Impact Factor: SJIF: 5.995

Available Online at www.journalijcar.org

Volume 6; Issue 5; May 2017; Page No. 3689-3693

DOI: http://dx.doi.org/10.24327/ijcar.2017.3693.0348

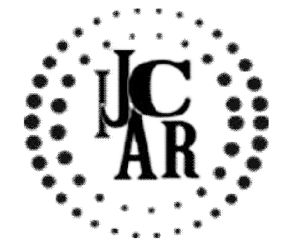

Research Article

\title{
VIRTUAL LEARNING ENVIRONMENTS. A PROPOSAL FOR ITS EVALUATION
}

\section{Rubí Estela Morales Salas and Daniel Montes Ponce}

Sistema de Universidad Virtual, Universidad de Guadalajara. México

\section{A R T I C L E I N F O}

\section{Article History:}

Received $7^{\text {th }}$ February, 2017

Received in revised form $12^{\text {th }}$ March, 2017

Accepted $15^{\text {th }}$ April, 2017

Published online $28^{\text {th }}$ May, 2017

\section{Key words:}

Checklist format, Evaluate, Virtual Learning Environment (VLE)

\begin{abstract}
A B S T R A C T
The learning environments facilitate to those who are in it, the promotion and reinforcement of the feelings of security, dignity and solidarity, involving actions, experiences, attitudes and multiple relationships with the environment and the infrastructure necessary for the accumulation of the purposes that are made explicit in any educational proposal.

This article proposes an instrument in a Checklist format to evaluate any platform as a Virtual Learning Environment, responding to four spaces or general indicators: Information Space, Mediation/Interaction Space, Instructional Design Space and Exhibition Space. Likewise, criteria are used according to the functions and activities carried out by the advisor and virtual student. These in turn arise from the analysis and interaction of the consultants achieved in discussion forums and portfolio activities through collaborative work.

It is classified as a qualitative research, descriptive in nature, as it is not limited to data collection, but also refers to and analyzes the interaction of the consultants achieved in the discussion forums and portfolio activities through the collaborative work of the course "Virtual Learning Environments" developed in a virtual learning environment.
\end{abstract}

Copyright $@ 2017$ Rubi Estela Morales Salas and Daniel Montes Ponce. This is an open access article distributed under the Creative Commons Attribution License, which permits unrestricted use, distribution, and reproduction in any medium, provided the original work is properly cited.

\section{INTRODUCTION}

In a preliminary way, a virtual learning environment can be conceived as a space where activities are carried out using technologies such as the Internet, multimedia materials and learning objects, among others, which at the same time have significantly changed traditional education.

These environments create situations for the student to apply knowledge, experiences and new elements that form processes of analysis, reflection and understanding, but above all of content appropriation, where the distance aspect is present, without a physical presence.

Belloch (2012) considers that an environment is a combination of resources, interactivity, support and structured learning activities, that in order to develop them we must know the strengths and limitations of the computer support or virtual platform to be used.

The platforms are adaptable to the characteristics and needs of the user since they have different roles, teachers, tutors, administrators and students, thus enabling communication and interaction between student, teacher and tutor.

*Corresponding author: Rubí Estela Morales Salas Sistema de Universidad Virtual, Universidad de Guadalajara. México
UNESCO (1998) in its World Education Report notes that virtual learning environments are a whole new form of Educational Technology and offer a complex array of opportunities and tasks to educational institutions around the world, the environment of Virtual learning defines it as an interactive computer program of pedagogical character that has an integrated communication capacity, that is, is associated with New Technologies.

"A Virtual Learning Environment is the set of environments of interaction, synchronous and asynchronous, where, based on a curricular program, the teaching-learning process is carried out, through a learning management system" LópezRayón, Escalera, Ledesma 2002.

For Monroy et al (2013) they refer that a learning environment is the gathering of factors within the set of interactions between individuals affect, for the purpose of learning. These factors are physical, psychological, technological, content, interaction and very important the efficient communication.

They mention that the characteristics of learning environments are varied, but can be referred to as follows:

- Facilitate the promotion and reinforcement of feelings of security and dignity to those who are in it.

- Promotion and reinforcement of the experiences, attitudes and multiple relationships with the environment and the necessary infrastructure for the 
accumulation of the purposes of an educational proposal.

- It refers to the physical environment.

- It also refers to the interactions produced in the learning environment.

- It is based on a need.

- Consider the general psychological processes and principles of learning.

- Consider the nature of the contents and processes required for their learning.

- Should consider the characteristics of who you are targeting.

- It is a defined environment.

- It is a moving environment.

- It can be in presence or virtual.

Thus, these learning environments benefited from the incorporation of technologies and the internet, are strengthened in Distance Education, where activities are developed without physical presence between students and counselors, on a platform with the use and help of various media with a particular instructional design.

Likewise, the virtual learning environment has involved forms of work where the technology and interaction between the participants is implemented, developing learning in online courses where planning, instructional design, monitoring and evaluation are required.

In that sense, the means, instruments, materials, a certain methodology and the interaction between the participants do not guarantee the learning and that they have optimal results, Avila and Bosco (2001) refer that these contribute to the realization of a determined way, requires for this, the process of construction, assimilation, understanding, responsibility, and determination on the part of the student.

Students then learn certain content, develop skills, creativity and skills, where they interact with the reality of the context where it is developed, using reason, making value judgments, proposing strategies or solving problems.

For this, in a Virtual Learning Environment, where the student is responsible for their development and progress in the program they are studying, autonomous learning is decisive.Valle A. et al. (2007), points out that autonomous learning refers to the student's degree of intervention in the establishment of his/her objectives, procedures, resources, evaluation and learning moments, from the active role they must have in face of the current training needs, in which the student can and should contribute their previous knowledge and experiences, from which it is intended to revitalize learning and give it meaning.

Marti (2000) states that it is the intellectual process, through which the subject implements cognitive and metacognitive strategies, sequential, objective, procedural and formalized to obtain strategic knowledge. This process is governed by principles of action such as: a manifest interest in reasons that motivate the deliberate action; the recognition of previous learning experiences; the establishment of new relationships between learning - work - everyday life, as well as between theory and practice; the identification of intrinsic motivation and the development of the personal potential of selfregulation.

For Martínez, (2005), autonomous learning is a process where students self-regulate their learning and become aware of their own cognitive and socio-affective processes. This awareness is what is called metacognition. The pedagogical effort in this case is oriented towards the formation of subjects focused on solving concrete aspects of their own learning, and not only in solving a specific task, that is, to guide the student to question, to review, to plan, to control and to evaluate their own learning action.

Based on the above, then we can affirm that the autonomous learning is favored with the interaction between the participants, where the messages and the contributions, when being exhibited and shared in the platform, allow the students to receive from their messages contributions, feedback, doubts, refutations, questions, congratulations, etc., where it allows the student to reflect, analyze and deepen the contribution, and with it the ability to modify or debate and defend the content of their messages, all this is supposed to allow them to experience a learning.

It is for this reason that Distance Education, and specifically virtual learning environments, must be addressed in a profound way, to identify what is happening inside the environment, how activities are performed on the platform, if the planned learning is what is being developed, and especially if the spaces available to the platform are desirable for the achievement of these learning and objectives.

Then, the spaces that have the Virtual Learning Environment, specifically in the platform where educational programs are developed, in this case we will refer to the Educación Media Superior and Educación Superior of the System of Virtual University (SUV) of the University of Guadalajara (UdeG), it is indispensable to investigate them, since there is no physical presence of a teacher, advisor, facilitator or teacher who guides, transmits or orient the contents; as well as students are not subject to a predetermined schedule, facilities or transfers; that is to say that knowledge is approached in a flexible way, which also adjusts to the needs and availability of time according to the student regardless of age, social status or personal status.

Even though in these environments, the center is the student and the autonomous learning, the teacher, who within the model of the SUV, is called an advisor, continues to be a determining figure in student learning, as well as being an expert in its Area and in the subject that advises, needs to have theoretical knowledge and technical and pedagogical skills to be able to propitiate and motivate learning in the student. It also serves as a mediator of the educational process in the field of planning, work dynamics, instructional design and learning strategies for the purpose of knowledge construction. This 
leads us to the consultant to achieve this mediation with optimal quality, must manage the platforms in an organized, clear and concrete manner. But what will have to contain the platforms that allow to meet these quality standards?

For Boneu (2007) there are four basic, and essential, characteristics that any platform like a Virtual Learning Environment should have:

- Interactivity: get the person who is using the platform is aware that is the protagonist of their training.

- Flexibility: a set of functionalities that allow the e-learning system to have an easy adaptation in the organization where it is wanted to implement, in relation to the institutional structure, the study plans of the institution and, finally, to the contents and Pedagogical styles of the organization.

- Scalability: the ability of the e-learning platform to work equally with a small or large number of users.

- Standardization: Ability to import and export courses in standard formats like SCORM (Sharable Content Object Reference Model) that are a set of standards and specifications that allows to create structured pedagogical objects.

One of the main characteristics of the Virtual Learning Environments from the perspective of communicative processes is that they must have very limited spaces, which Chan refers to in the following way:

- "The information space is where the various types of inputs to be processed are found. In this space you can present the information organized or to be inquired by the students.

The information can be provided by various means: exhibitions, documents, databases, images, graphics.

- The interaction space is one in which situations are arranged so that the subjects of the information exchange information of all kinds: opinions, products of their work, doubts, projects, creative expressions.

- In the production space there are tools and devices for information processing, performing exercises, problem solving.

- The exhibition space is characterized by being a space for the circulation of the products of learning, for the socialization of its results. In this space students express the achievements of their effort and in turn expose what they find in the products of others. (2004, p.10).

\section{Development}

Based on the above, for the present study, the following research questions were formulated:

1. Does the platform as a virtual learning environment of the SUV have defined spaces?

2. Does the platform as AVA of the SUV in its High School and Higher Education courses present the information organized?

3. Does the mediation and interaction that is given on the platform as AVA of the SUV in its Bachillerato and
Higher Education courses contain sufficient elements for the exchange of information of all kinds?

4. Does the instructional design of the courses hosted in an AVA of the SUV in its courses of Bachillerato and Higher Education, present sufficient elements to process all type of information?

5. Can the advisor and student evaluate the interaction spaces of the virtual learning environment of the SUV?

\section{Context}

The present study was carried out in the Virtual University System of the University of Guadalajara, with 40 advisers who teach both in High School General by Interdisciplinary Areas and in Higher Education Programs, during the period from August to December of 2016.

It consisted of a course-workshop where the consultants would discuss how to manage virtual learning environments to favor and induce students' learning.

For this study, the criteria for selecting the participating consultants were to be a High School General teacher by Interdisciplinary Areas and adviser of any degree program offered in the SUV; have a minimum of three years of teaching experience and knowledge about virtual environments.

\section{METHODOLOGY}

It is classified as a qualitative research, descriptive in nature, as it is not limited to data collection, but also refers to and analyzes the interaction of the consultants achieved in the discussion forums and portfolio activities through the collaborative work of the course "Virtual Learning Environments" developed in a virtual learning environment. To express Danhke, (1989) quoted in Hernández, Fernández and Baptista, (2006, p. 102) "These studies measure concepts, collect information, data (variables), dimensions, components of the phenomenon to investigate."

From the analysis of the consultants participating in the workshop course, an instrument was designed under the format "Checklist to evaluate Virtual Learning Environments", using as indicators the spaces from the perspective of communicative processes, referred to by Chan (2004), that is to say: informative, interactive, production and exhibition. With some adaptations to the same taking into account the agreements of the advisers.

\section{RESULTS}

The general indicators that were included for the design of the Checklist to evaluate Virtual Learning Environments were:

a) Information Space, b) Mediation / Interaction Space, c) Instructional Design Space and d) Exhibition Space.

Likewise, criteria were used according to the functions and activities carried out by the consultant and virtual student. These in turn arise from the analysis and interaction of the consultants achieved in discussion forums and portfolio activities through collaborative work.

The following is the instrument in its final version: 
Checklist to Evaluate Virtual Learning Environments

Please answer according to your perception, marking with a cross $(\mathrm{X})$

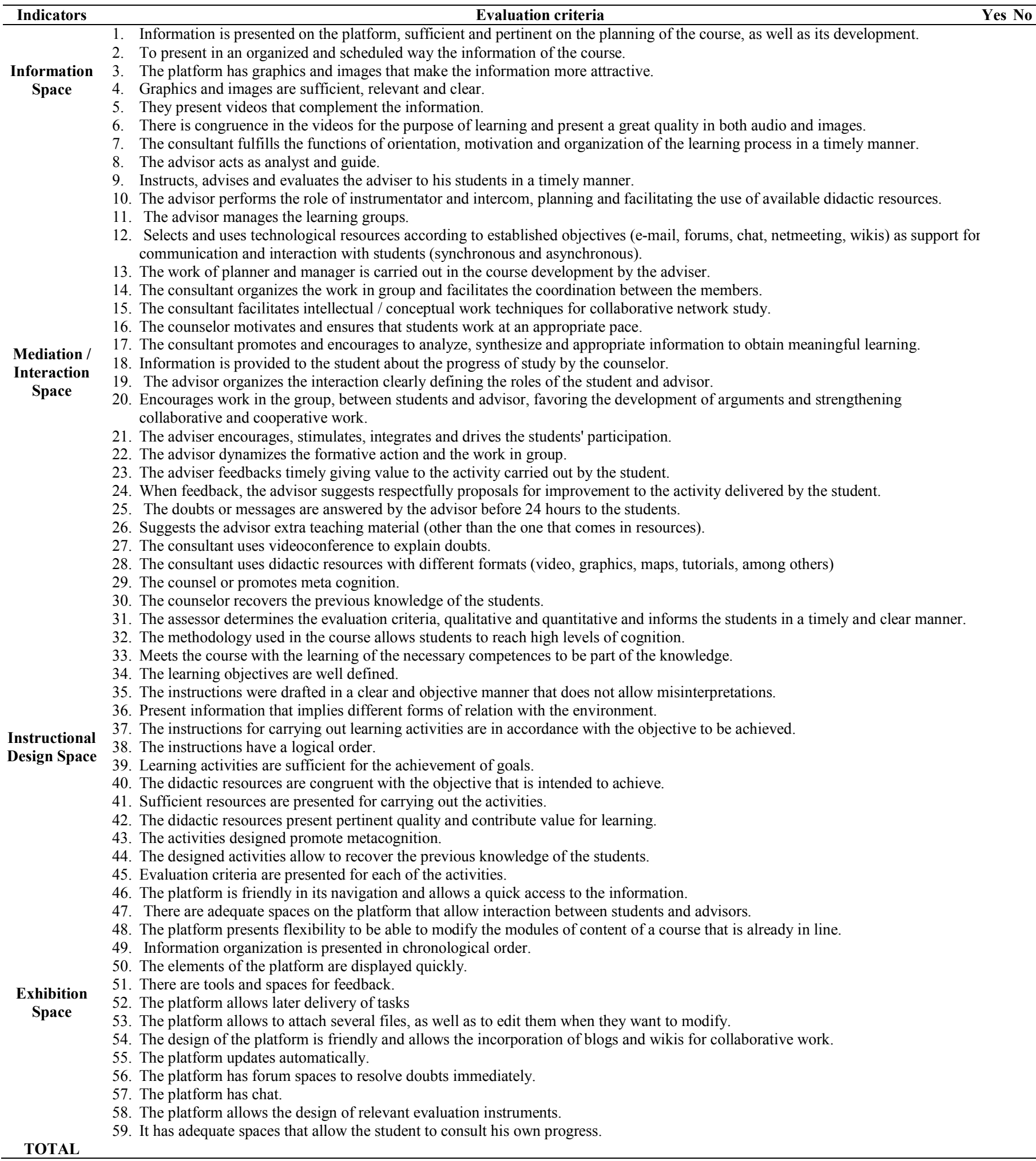

Elaborated by Morales, R. (2016), based on: Dimensions of the Checklist adapted from Chan, María Elena. (2004) .Trends in educational design for digital learning environments.

\section{CONCLUSIONS}

After the analysis and discussion of the participants in both forum and in the portfolio, the final version of the instrument presented was achieved thanks to the contribution of ideas, elaboration of multiple activities and participation in forums, thus achieving the conjunction of all that information the classification of multiple criteria in each of the four indicators shown in the first column.
In a second stage will proceed to the application of itself. The design was designed so that both advisers and students could answer, taking care of the sense of the language and its writing.

We think that it can be very useful to improve the spaces of an AVA, since the diversity of criteria that this instrument presents include in a detailed way what according to the perception and experience of the participating consultants 
would require the SUV platform as a virtual environment Learning.

We know that there are many aspects that should be evaluated in an AVA, however, keeping the platforms updated is a guarantee that the student will acquire the skills effectively and with optimal quality.

It is important that with the results obtained those involved in these virtual learning spaces take into account the following aspects to improve them:

\section{Difficulties arising from the operation of digital communication channels}

- Slow transmission of information, especially observable when receiving compressed or real-time multimedia documents.

- Unexpected interruption of communication.

- High cost of flat rates.

- "Delay" effect in audiovisual communication in real time.

- Frequent failures in information servers.

- Interruptions in the electricity supply.

\section{Difficulties derived from the technological-educational quality of the information}

- Obsession for the generation of literary content.

- Carelessness in the aesthetic quality of graphic and multimedia design.

- Excessive presence of linear text.

- Little creativity and semantic neglect in visual texts and especially in photographs.

- Incorrect approach to charts and graphs.

- Existence of communicative noise (poor figurebackground interaction, inadequate vocabulary, blurry visual texts, unfocused multimedia or problems with acoustic, reception, etc.).

\section{Difficulty derived from the methodological and} organizational design of the training action

- Obsession with the transmission of content.

- Neglect of objectives related to the social and ethical formation of citizens.

- Tendency to use behavioral methodologies.

- Obsession for efficiency in the acquisition of knowledge.

- Tendency to the evaluation of results, forgetting in many cases the analysis of the processes of knowledge construction.

- Excessive tendency towards the use of systems of monitoring, evaluation and automatic tutoring.

- Neglect in the design of instructional strategies based on the design of "many-to-many" intercommunication activities aimed at promoting the creation of shared knowledge.

- Progressive demotivation and occasional abandonment of the learning process in those cases in which the methodological and organizational designs do not favor the establishment of interpersonal (convivial and online) relationships between students and teachers and between students. "(Torres and Ortega, 2003).

\section{Bibliography}

Aguado, D., Arraz, V. (2005). Desarrollo de competencias mediante blended learning: un análisis descriptivo. Píxel-Bit, Revista de Medios y Educación, n. ${ }^{\circ}$ 26, pp. 79-88. Available at http://www.rieoei.org/ deloslectores/1118Arranz.pdf

Álvarez, V.M., et al. (2008). Presente y futuro del desarrollo de plataformas Web de elearning en educación superior. V Simposio Pluridisciplinar sobre Diseño y Evaluación de Contenidos Educativos Reutilizables. Universidad Pontificia de Salamanca. Available at http://www.web.upsa.es/spdece08/contribuciones/118 SPEDECE08Revisado.pdf

Belloch, C. (2012) Entornos virtuales de aprendizaje. Recovered from http://www.uv.es/bellochc/ pedagogia/EVA3

Boneu, J.M. (2007). Plataformas abiertas de e-learning para el soporte de contenidos educativos abiertos. Revista de Universidad y Sociedad del Conocimiento, Vol.4, $\mathrm{n}^{\circ} 1$. Available at http://www.uoc.edu/rusc/4/1/dt/esp/ boneu.pdf

Chan, M.E. (2004). Tendencias en el diseño educativo para entornos de aprendizaje digitales. Revista Digital Universitaria. 10 de noviembre 2004 - Volumen 5 Número 10 • ISSN: 1067-6079

González, M.A. (2000). Evaluación de ambientes de aprendizaje, de Miguel Ángel González Castañón, Available at: http://www.niee.ufrgs.br/eventos/RIBIE/ 2000/papers/067.htm

Iglesias, M.L. (2008). Observación y evaluación del ambiente de aprendizaje en Educación Infantil: dimensiones y variables a considerar, de María Lina Iglesias Forneiro, Available at: http://www.rieoei.org/rie47a03.htm

López E., Ledesma, A. (2002). Ambientes Virtuales de Aprendizaje, Instituto Politécnico Nacional, Presimposio Virtual SOMECE http:/ www. somece.org.mx/virtual2002

Martí, E. (2000). "Metacognición y estrategias de aprendizaje", en Pozo, J.I. y Monereo, C. El aprendizaje estratégico. Madrid: Aula siglo XXI, Santillana.

Martínez, J.R. (2004). Concepción del aprendizaje, metacognición y cambio conceptual en estudiantes universitarios de Psicología. Tesis doctoral, Universidad de Barcelona

Monroy, E., Ladino R. y Sánchez S. (2013). Diseño de un ambiente de aprendizaje como herramienta para el área de tecnología e informática. Memorias Congreso Investigación y Pedagogía. Tunja, Número 02 Octubre/ 2013 ISSN 2256-1951. Available at: http://tics.uptc.edu.co/eventos/index.php/cong_inv_ped agogia/con_inv_pedag/paper/viewFile/11/11

Valle, A. et al. (2007). "Metas académicas y estrategias motivacionales de autoprotección". Electronic Journal of Research in Educational Psychology.No. 13.Vol. 5 (3.) pp. 617-632. [http://www.investigacionpsicopedagogica.org/revista/articulos/13/espannol/Art_ 13_207.pdf Abril 2011] 